Sir George Beilby Memorial Fund: Award to Dr. A. S. C. Lawrence

THE administrators of the Sir George Beilby Memorial Fynd, representing the Institute of Metals, the Royal Institute of Chemistry and the Society of Chemical Industry, have made an award from the Fund for 1948 of one hundred and fifty guineas to Dy. A. S. C. Lawrence, in recognition of his research work in colloid science with special reference to lubrication and fuel oils. Dr. Lawrence was born in London and educated at Christ's Hospital ; in 1920 he became junior lecturer and research assistant at the Royal Institution, first to Sir James Dewar and in 1924 to Sir William Bragg. Later he worked at Cambridge in the Department of Physical Chemistry and also in Prof. E. K. Rideal's newly formed Laboratory of Colloid Science, where he remained until 1942 investigating various aspects of anomalous viscosity, including joint work with Dr. J. Needham on myosin, and on solubilization and related topics. A long investigation was made of soap-oil systems during this period for the Fuel Research Division of the Department of Scientific and Industrial Research. In 1939, researches on coal-in-oil suspensions and on coal tar were carried out for the Fuel Research Station. In 1942, Dr. Lawrence went to the Imperial College of Science and Technology, London, as head of the research team of the joint Admiralty and Ministry of Supply advisory service on lubrication. In 1943 he worked on de-icing ships; later he carried out researches on emulsions of sea water in fuel oil and related problems, including investigations in port areas and in H.M. ships, and eventually became advisor on fuel oil to the Engineer-in-Chief, Admiralty. In 1947 he was appointed senior lecturer in chemistry in the University of Sheffield, a post which he now holds. Dr. Lawrence is the author of numerous papers, mainly dealing with colloids, published in the Progeedings of the Royal Society and other journals.

Nip

\section{Archæological Discoveries in Moravia}

Excavatrons at Věstonice in South Moravia were resumed in 1948, and Czechoslovak archæologists have already mady noteworthy progress in revealing what has heen described as a "diluvial Pompeii, preserved $\mathrm{S}$. by a downpour of volcanic ash but by the slowaccumulation of a blanket of loess". About $3 \rho, 00$ y ars ago, hunters of mammoths dwelt in seturements along the route of animal migration through the Moravian Gap. These people not only attained skill in the chase, but also possessed considerable artistic talent. There is also evidence that they could count. More objects have recently been added to the collections of worked bones, skulls, utensils and plastic figures that had accumulated from pre-war excavations. The first discovery was that of the remains of four mammoths, each of which is estimated to have weighed eight or ten tons. In what was a human settlement, a plastic model, two inches long, of a woman's head has just been unearthed. It is not so striking as the model, five inches high, known as the Verstonice Venus (Nature, 131, 607; 1933), though it is of great interest on account of its age. A well-preserved baked clay model of a bear has also been discovered as well as a curious whistle, which still functions, made from a mammoth's bone. Photographs of these objects, and an account of them by Dr. Edvard Cenek, was given in a recent issue of the Prague illustrated weekly Svět $v$ Obrazech.
Research in Travancore during 1939-46 J/6

THE University of Travancore Department of Research Report fow the Septennium 1939-1946 (pp. ix +594 Trifondrum, 1948) is an admirable illustrated Acg as non-technical as possible, of the acf Aritils of the Department during the period. It is infteded also as a basis of review on which future developments may be planned. The first part briefly reviews the history and organisation of the Depart. ment since its institution in 1937. The second part describes the organisation and activities of the Central Research Institute and of its several divisions of applied biology, applied chemistry, marine biology and fisheries, preventive medicine and statistics, and the observatory. The third part deals with the work of the University College, the Institute of Textile Technology and the College of Engineering, while among the appendixes is a list of research publications of the Department for 1939-46. Most of the research in this report deals with the application of science towards the study and utilization of the local crops, industries and resources of Travancore, and the work of the Department covers a very wide field.

\section{The Flamingo}

A RECENT isste British Bind (41, No. 12 ; December 1948) ontains a selection or a remarkable series of flographs of flamingos (Phoenicopterus ruber), Hakin by G. K. Yeates, W. E. Higham, T.W. Jeans and H. A. Patrick in the Camargue (Rhone delta) in May 1948. Until recently it has been doubtful whether the Camargue could be regarded as a breeding-place of flamingos; lut in June 1948 a large breeding-colony in a remote locality was 'discovered' by Yeates, Higham and Patrick. The locality appears to be the one in which flamingos most frequently breed, or attempt to breed, in the Camargue. When the photographs were taken, a large number of birds, estimated at approximately three thousand pairs, were breeding. In remarkable contrast to their sensitivity in the earlier stages of breeding, when they desert with great readiness, the birds are surprisingly approachable when the young are hatched. The nests are formed of mud scraped up by the birds to form a mound. They are usually made in shallow water and are raised until they are a few inches above water-level, although frequently the water afterwards drops, leaving them high and dry.

\section{Fauna of Australia}

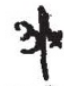

AN article by A. S. Le Souef in the Journal of the Society for the P esmation of the Fauna of the Empire shows how than mpact of civilization has altered the fauna of Anstralia. Over the last 150 years, introduced hammals like the fox, rabbit, hare, cat, pig, bo ok tat and common mouse have spread through the bushlands and are rapidly ousting the native marsupials and terrestrial birds. Already several species of wallabies, rat kangaroos, bandicoots and the marsupial wolf either are, or are on the verge of becoming, extinct. This is particularly so in the open districts of the southern half of the continent, and the Commonwealth Government is now considering the establishment of a fauna park in the vicinity of Canberra. The unique lyre-bird is reported to be holding its own against the fox and the cat; but the striped marsupial wolf may already be extinct. The article also contains an account of the effect of disturbances of the native fauna on general biological relationships. 